\title{
PENERAPAN MODEL PEMBELAJARAN TPS (THINK-PAIR-SHARE) BERBANTUAN MEDIA KARTU HURUF UNTUK MENINGKATKAN KEMAMPUAN MENGENAL HURUF
}

\author{
Nurul IIma ${ }^{1}$, I Ketut Pudjawan², \\ 1 Jurusan Pendidikan Guru Pendidikan Anak Usia Dini \\ 2, Jurusan Tekhnologi Pendidikan \\ Fakultas IImu Pendidikan \\ Universitas Pendidikan Ganesha \\ Singaraja \\ e-mail: nurulilma079@gmail.com¹, ketutpudjawan@gmail.com²,
}

\begin{abstract}
Abstrak
Penelitian ini dilatar belakangi oleh perkembangan bahasa anak khususnya pada pengenalan huruf. perkembangan bahasa memerlukan bimbingan yang lebih optimal karena sebagai modal anak untuk memasuki jenjang pendidikan sekolah dasar. Oleh karenanya penelitian ini bertujuan untuk meningkatkan kemampuan bahasa mengenal huruf yang diterapkan menggunakan model pembelajaran Think Pair Share (TPS) yang berbantuan media kartu huruf pada kelompok B3 TK Kartika VII-3 Singaraja tahun 2018/2019. Jenis penelitian yang digunakan adalah Penelitian Tindakan Kelas (PTK) yang dilaksanakan dalam dua siklus, subjek penelitian kelompok B3 TK Kartika Singaraja VII-3 Singaraja yang berjumlah 27 anak terdiri dari 9 anak perempuan dan 18 anak laki-laki. Objek penelitian adalah kemampuan bahasa anak dalam mengenal huruf. Pengumpulan data dalam penelitian ini dilakukan dengan media observasi. Metode analisis yang digunakan adalah metode analisis statistik deskriptif dan metode analisis deskriptif kuantitatif. Hasil analisis data pada penelitian ini menunjukkan bahwa terjadi peningkatan rata-rata presentase kemampuan bahasa mengenal huruf pada kelompok B3 sebesar $25.7 \%$ hal ini dapat dilihat dari adanya peningkatan rata-rata presentase kemampuan bahasa mengenal huruf anak pada siklus I sebesar 55.31\% dengan kriteria rendah menjadi 81,01\% pada siklus II dengan criteria tinggi. Dengan demikian, dapat disimpulkan bahwa penerapan model pembelajaran Think Pair Share (TPS) berbantuan media kartu huruf dapat meningkatkan kemampuan bahasa mengenal huruf anak kelompok B3 TK Kartika Singaraja Pada semester I tahun 2018/2019.
\end{abstract}

Kata Kunci : Think Pair Share, Kartu huruf, Mengenal

\section{Abstract}

This research is motivated by the development of children's language, especially in letter recognition. Language development requires more optimal guidance because as a child's capital to enter elementary school education. Therefore this study aims to improve the ability to recognize the language of letters applied using Think Pair Share (TPS) learning models assisted by letter card media in the TK Kartika VII-3 Singaraja B3 group in 2018/2019. The type of research used was Classroom Action Research (CAR) which was carried out in two cycles, the subject of research was the TK Kartika Singaraja VII-3 Singaraja B3 group, which consisted of 27 children, consisting of 9 girls and 18 boys. The object of research is the child's language ability to recognize 
letters. Data collection in this study was conducted with observation media. The analytical method used is descriptive statistical analysis method and quantitative descriptive analysis method.

The results of data analysis in this study indicate that an average increase in the percentage of language ability to recognize letters in the B3 group is $25.7 \%$. This can be seen from the increase in the average percentage of the ability of the language to recognize child letters in the first cycle of $55.31 \%$ with low criteria being $81.01 \%$ in cycle II with high criteria. Thus, it can be concluded that the application of Think Pair Share (TPS) learning models assisted by letter card media can improve the ability of the language to recognize the letters of the children of B3 TK Kartika Singaraja group in the first semester of 2018/2019.

Keywords: Think Pair Share, Letter cards, Know letters.

\section{Pendahuluan}

Pendidikan adalah usaha sadar untuk menumbuh kembangkan potensi sumberdaya manusia melalui kegiatan pembelajaran. Menurut Asyiah (2007:1),Anak Usia Dini (AUD) merupakan kelompok usia berada dalam proses perkembangan (tumbuh dan kembang) terjadi bersamaan dengan golden age masa (peka). Golden age merupakan waktu paling cepat untuk memberikan bekal yang kuat kepada anak. Dimasa peka kecepatan pertumbuhan otak anak sangat tinggi hingga mencapai 50 persen dari keseluruhan perkembangan otak anak selama hidupnya. Artinya : Golden Age merupakan masa yang sangat tepat untuk menggali segala potensi kecerdasan anak sebanyak-banyaknya.

Pendidikan Anak Usia Dini merupakan pendidikan yang diperuntukan bagi anak-anak sebelum memasuki jenjang pendidikan sekolah dasar. Pendidikan anak usia dini sangat penting bagi anak sebagai bekal persiapan pendidikan berikutnya. Maimunnah Hasan (2009:15), mengungkapkan bahwa pendidikan anak usia dini (PAUD) adalah jenjang pendidikan sebelum sekolah dasar yang merupakan suatu upaya dasar pembinaan yang ditujukan bagi anak sejak lahir sampai dengan usia enam tahun yang dilakukan melalui pemberian rangsangan pendidikan yang membantu pertumbuhan dan perkembangan jasmani dan rohani agar anak memiliki kesiapan dalam memasuki pendidikan lebih lanjut.

Salah satu perkembangan yang sangat penting untuk persiapan pada jenjang pendidikan sekolah dasar adalah perkembangan bahasa. Menurut (Haryuni,2013), Upaya pembinaan melalui pendidikan anak usia dini yang ditujukan bagi anak-anak bertujuan memfasilitasi pertumbuhan dan perkembangan anak secara menyeluruh atau menekankan pada seluruh aspek perkembangan anak yang meliputi: nilai-nilai agama dan moral, bahasa, fisik motorik, sosialemosional dan seni.

Perkembangan Bahasa sangatlah penting untuk kehidupan anak dimasa mendatang, Pengembangan Bahasa anak beda halnya dengan pengembangan pada manusia dewasa. Karena dimasa ini anak-anak masih cenderung tertarik dengan hal yang bernuansa permainan dan menggunakan pendekatan yang berorietasi Belajar Melalui Bermain dengan pelaksanaan belajar melalui bermain pengalaman-pengalaman yang ditemukan oleh anak akan lebih melekat pada otaknya dan lebih menunjang pada daya ingatnya.

Pada perkembangan anak usia dini pengenalan huruf merupakan bagian dari aspek perkembangan bahasa anak yang perlu di kembangkan dengan memberi stimulasi secara optimal sejak usia dini. Tadkirotun Musfiroh (2009:10), "mengungkapkan bahwa stimulasi pengenalan huruf adalah merangsang anak untuk mengenali, memahami, dan menggunakan symbol tertulis untuk berkomunikasi". perkembangan bahasa memerlukan bimbingan yang lebih optimal karena sebagai modal anak untuk memasuki jenjang pendidikan sekolah dasar.

Kegiatan pengenalan huruf pada kelompok B3 dengan cara guru menulis di papan tulis anak menyebutkan lafal tersebut dan menulisnya. Kegiatan mengenal huruf juga dilakukan dengan menghubungkan garis putus-putus membentuk pola suatu huruf menggunakan LKA. Setelah dikerjakan guru mengajak anak untuk menyebut huruf yang sudah ditulisnya. 
Sehubungan dengan hal tersebut, dari hasil diskusi dan observasi yang dilakukan di kelompok B3 TK Kartika VII-3 Singaraja. Di peroleh hasil kemampuan bahasa khususnya kemampuan mengenal huruf belum berkembang secara maksimal. Dibandingkan dengan aspek perkembangan kognitif, fisik motorik, seni, sosial emosional dan Nilai agama moral. Dari 27 anak kelompok B3 ditemukan 20 anak mengalami kesulitan dalam mengenal huruf, taraf perkembangan masih pada tahap penilaian MB (Mulai berkembang). Sedangkan 7 anak lainnya taraf penilaian BSH (Berkembang sesuai harapan). Pada obeservasi ini belum ditemukan anak yang penilaiannya pada taraf BSB (Berkembang sangat baik). Kesulitan anak nampak apabila disuruh menyebutkan huruf dengan system acak.

Guru memiliki peranan yang sangat penting untuk menentukan model pembelajaran serta media yang akan digunakan. Peranan guru yang kreatif diperlukan dalam upaya memotivasi anak agar mau belajar sehingga potensi anak teraktualisasi dalam pembelajaran. Kreativitas guru terlihat dari cara guru menerapkan media, strategi, metode dan tehnik pembelajaran. "Guru yang kreatif adalah seorang guru yang luwes dan optimis dalam menyelesaikan masalah pembelajaran dengan cara yang berbeda serta menciptakan hal yang baru sehingga tercapai suatu tujuan pembelajaran" (Retnowati, 2013:4). Berdasarkan pendapat di atas, guru yang kreatif adalah kemampuan seorang guru untuk menciptakan suatu pembelajaran yang mampu menarik minat anak sehingga mendatangkan semangat belajar anak.

Menurut (Trianto, 2009:81), "Salah satu model pembelajaran kooperatif yang dapat digunakan guru untuk meningkatkan minat belajar anak adalah model pembelajaran Think Pair Share (TPS)". Think Pair share suatu cara yang efektif untuk membuat variasi suasana pola diskusi di kelas". Dalam model pembelajaran Think Pair Share, anak di tuntut untuk bekerjasama dalam kelompok kecil yang heterogen. Hal ini memungkinkan anak untuk terlihat aktif pada proses pembelajaran serta memungkinkan terjadinya komunikasi dan interaksi yang lebih berkualitas antara anak dalam kelompok dan anak dengan guru. Menurut Wulandary (2013), "model Think Pair Share telah diterapkan dalam penelitian terdahulu dan memiliki keunggulan yaitu optimalisasi partisipasi anak,sehingga beberapa anak yang kuranmg tidak merasa minder terhadap anak yang lain karena anak yang mampu tersebut juga ikutberpartisipasi

menyumbangkan pemikirannya". Dengan demikian anak yang kurang mampu akan terpacu pemikiran untuk meningkatkan hasil belajarnya.

Berdasarkan permasalahan yang ada di TK Kartika VII-3 Singaraja dapat diterapkan model pembelajaran Think Pair Share. Selain penggunaan model pembelajaran yang tepat, penggunaan media pembelajaran juga sangat berpengaruh untuk minat dan hasil belajar anak. Maka diperlukan juga suatu media yang mampu menarik minat anak sehingga tidak merasa bosan. Media kartu huruf dirasa cocok meningkatkan pengenalan lambang huruf pada anak dipadukan dengan metode pembelajaran Think Pair Share. Berdasarkan permasalahan di TK Kartika VII-3 Singaraja, maka dirancang sebuah penelitian yang berjudul: "Penerapan Model Pembelajaran TPS (Think Pair Share) Berbantuan Media Kartu Huruf Untuk Meningkatkan Kemampuan Mengenal Huruf Pada Anak Kelompok B Semester I di TK Kartika VII-3 Singaraja Tahun 2018/2019.

\section{Metode}

Penelitian ini dilaksanakan di kelompok B3 pada Semester I di TK Kartika VII-3 JI.Pahlawan Singraja Bali tahun pelajaran 2018/2019. Pelaksanaan penelitian ini dilaksanakan dalam siklus tindakan. Setiap siklus dalam penelitian ini terdiri dari empat tahapan yaitu tahap perencanaan, tahap pelaksanaan, pengamatan, dan refleksi. Penelitian ini dilaksanakan pada bulan September s/d Oktober 2018.

Subjek dalam penelitian ini adalah anak kelompok B3 Semester I TK Kartika

VII-3 Singaraja, dengan jumlah anak sebanyak 27 orang, yang terdiri dari 9 orang anak perempuan dan 18 orang anak laki-laki.

Objek dalam penelitian ini adalah kemampuan bahasa pengenalan huruf terkait penerapan model pembelajaran think pair share (TPS) pada anak kelompok B3 TK Kartika VII-3 Singaraja. 
Secara operasional yang termasuk kemampuan bahasa dalam bentu non verbal. Yang merupakan pengenalan huruf kepada anak guna untuk mempermudah perkembangan anak dalam membaca dan menulis untuk mempersiapkan anak melanjutkan pendidikan tingkat dasar.

Penelitian ini tergolong penelitian tindakan kelas (PTK). Pada hakikatnya PTK merupakan penelitian yang bertujuan untuk melakukan perbaikan terhadap proses pembelajaran. Terkait dengan hal tersebut, menurut Sanjaya (2011:26), "penelitian tindakan kelas merupakan proses pengkajian masalah pembelajaran di dalam kelas melalui refleksi diri dalam upaya untuk memecahkan masalah dengan melakukan berbagai tindakan yang terrencana dalam situasi nyata." Menurut Trianto (2011:16), "penelitian tidakan kelas merupakan suatu penelitian dengan mencermati kegiatan pembelajaran yang diberikan tindakan, dengan tujuan untuk memecahkan masalah atau meningkatkan mutu pembelajaran di kelas tersebut." Menurut Arikunto, dkk. (2015:1) "penelitian tindakan kelas merupakan suatu pencermatan terhadap kegiatan belajar berupa sebuah tindakan yang sengaja dimunculkan dan terjadi dalam sebuah kelas secara bersama."

Dengan demikian dapat disimpulkan bahwa, penelitian tindakan kelas merupakan penelitian yang dilakukan guru untuk mengkaji masalah pembelajaran melalui refleksi diri, memperbaiki strategi dalam kegiatan proses belajar mengajar dengan memberikan sebuah tindakan.

Penelitian ini merupakan penelitian tindakan kelas yang dirancang dalam siklus tindakan. Setiap siklus dalam penelitian tindakan kelas ini terdiri dari empat tahapan penting yaitu perencanaan, pelaksanaan, pengamatan, dan refleksi. Adapun siklus penelitian tindakan kelas (PTK) ini adalah sebagai berikut.

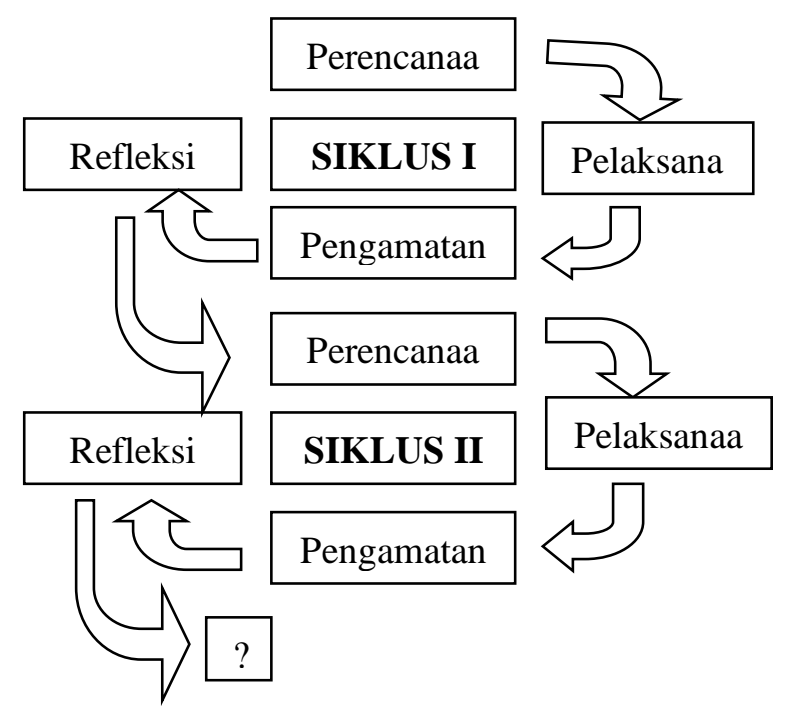

Gambar 01. Gambar Rancangan Penelitian Tindakan Kelas (Sumber: Arikunto, dkk. 2015:42)

(1). Perencanaan tindakan, pada tahap ini menjelaskan tentang apa, mengapa, kapan, dimana, oleh siapa, dan bagaimana tindakan tersebut dilakukan". Dalam tahap menyusun perencanaan ini ditentukan titik atau fokus peristiwa yang perlu mendapatkan perhatian khusus untuk diamati. Menentukan indikator, menyusun peta konsep,menyusun rencana pelaksanaan pembelajaran mingguan (RPPM), menyusun rencana pelaksanaan pembelajaran harian (RPPH), serta instrumen penilaian.(2) Pelaksanaan, pelaksanaan merupakan implementasi atau penerapan isi rancangan yaitu mengenai tindakan di kelas". Kegiatan yang dilakukan dalam tahap ini adalah melaksanakan kegiatan yang telah dirumuskan dalam rancangan tindakan. (3) Pengamatan. kegiatan pengamatan yang dilakukan pada saat tindakan sedang dilakukan. Kegiatan yang dilakukan pada rancangan pengamatan ini adalah mengamati kemampuan bahasa pengenalan huruf pada anak setelah diterapkannya model pembelajaran think pair share". Peneliti melakukan pengamatan secara langsung saat melaksanakan kegiatan pembelajaran agar memperoleh data 
yang akurat. (4) Refleksi. kegiatan refleksi merupakan kegiatan untuk mengemukakan kembali apa yang sudah dilakukan". Kegiatan refleksi ini dilakukan untuk melihat kekurangan dan kelebihan dalam kegiatan pembelajaran menggunakan model pembelajaran think pair share. Kemudian merangkum kendala-kendala selama melakukan tindakan dan mencari solusi untuk mengatasi kendala tersebut.

Pengumpulan data dalam penelitian ini menggunakan metode observasi dan metode pencatatan dokumen. Menurut Hasan (2003:17), "pengamatan atau observasi adalah cara pengumpulan data dengan terjun langsung dan melihat langsung ke lapangan terhadap objek yang diteliti". Sedangkan menurut Sukardi (2012:78) "observasi adalah instrumen yang sering dijumpai dalam penelitian pendidikan". Instrumen observasi akan lebih efektif jika informasi yang hendak diambil berupa kondisi atau fakta alami, tingkah laku dan hasil kerja responden dalam situasi alami. Metode observasi merupakan cara memperoleh data yang lebih dominan menggunakan indera penglihatan (mata) dalam proses pengukuran terhadap suatu objek. Dalam penelitian ini, metode observasi digunakan untuk mengumpulkan data kemampuan bahasa lisan pada anak.

Menurut Sukardi (2012:81) untuk memperoleh data dari responden dapat menggunakan teknik dokumentasi. Pada teknik ini, peneliti dapat memperoleh informasi dari bermacam-macam sumber tertulis atau dokumen yang ada pada responden atau tempat di mana responden tinggal maupun melakukan kegiatan sehari-harinya. Sedangkan menurut Agung (2014:106), "metode pencatatan dokumen merupakan cara memperoleh data dengan jalan mengumpulkan segala macam dokumen dan melakukan pencatatan secara sistematis". Berdasarkan pendapat tersebut, dapat disimpulkan bahwa metode pencatatan dokumen pada prinsipnya merupakan cara untuk melengkapi data yang diperlukan dengan melihat berbagai informasi yang ada. Dalam penelitian ini, metode pencatatan dokumen digunakan untuk mengumpulkan data kemampuan bahasa lisan anak.

Instrumen pengumpulan data yang digunakan dalam penelitian ini adalah lembar observasi. Observasi dilakukan terhadap kegiatan peneliti dan anak dalam menerapkan model pembelajaran think pair share Menurut Dimyati (2013:96), "setiap kegiatan yang diobservasikan dikategorikan ke dalam kualitas yang sesuai dengan kemampuan anak". yaitu anak belum berkembang dlsingkat (BB), anak mulai berkembang disingkat (MB), anak berkembang sesuai harapan disingkat (BSH), anak mampu berkembang sangat baik di singkat (BSB). Pedoman observasi adalah alat yang digunakan untuk acuan pengamatan, untuk mengetahui sejauh mana peningkatan kemampuan bahasa lisan anak. Pedoman observasi disusun untuk memudahkan dalam melakukan pengamatan terhadap proses pembelajaran.

Setelah data dalam penelitian ini terkumpul maka selanjutnya dilakukan analisis data. Dalam penelitian ini menggunakan metode analisis statistik deskriptif dan metode analisis deskriptif kuantitatif.

Analisis statistik deskriptif adalah suatu cara pengolahan data yang dilakukan dengan jalan menyususn secara sistematis dalam bentuk angka-angka atau persentase, mengenai suatu objek yang diteliti sehingga diperoleh kesimpulan umum." Dalam penerapan metode analisis statistik deskripif, data yang diperoleh dari hasil penelitian disajikan ke dalam 1) tabel distribusi frekuensi, 2) menghitung angka rata-rata atau mean (M), 3) menghitung modus (Mo), 4) menghitung median (Me), 5) menyajikan ke dalam grafik.

Metode analisis deskriptif kuantitatif adalah suatu cara pengolahan data yang di lakukan dengan jalan menyusun secara sistematis dalam bentuk angka-angka atau persentase mengenai keadaan suatu objek yang diteliti, sehingga diperoleh kesimpulan umum".Metode analisis deskriptif kuantitatif ini digunakan untuk menentukan tinggi rendah data kemampuan bahasa mengenal huruf yang ditentukan dengan menggunakan pedoman konversi Penilaian Acuan

Patokan (PAP) skala lima.

Tingkat kemampuan bahasa mengenal huruf yang diperoleh anak hasilnya dikonversikan dengan cara, membandingkan angka rata-rata persen dengan kriteria penilaian acuan patokan (PAP) skala 5 sebagai berikut. 
Tabel 01. Tabel Pedoman Konversi PAP Skala Lima tentang Tingkat Kemampuan Bahasa Lisan

\begin{tabular}{|c|c|}
\hline $\begin{array}{c}\text { Persentase } \\
\text { Kemampuan } \\
\text { Bahasa Lisan }\end{array}$ & $\begin{array}{c}\text { Kriteria } \\
\text { Kemampuan } \\
\text { Bahasa Lisan }\end{array}$ \\
\hline $90-100$ & Sangat Tinggi \\
$80-89$ & Tinggi \\
$65-79$ & Sedang \\
$55-64$ & Rendah \\
$0-54$ & Sangat Rendah \\
\hline
\end{tabular}

(Sumber: Agung, 2014:145)

Kriteria keberhasilan pada penelitian ini adalah adanya peningkatan dalam kemampuan bahasa mengenal huruf pada anak kelompok B3 TK Kartika VII-3 Singaraja. Penelitian ini dinyatakan berhasil jika terjadi peningkatan skor rata-rata dari siklus I ke siklus II dan jika dikonversikan pada pedoman PAP Skala lima tentang tingkat kemampuan bahasa keaksaraan anak berada pada rentang 80-89 dengan kriteria tinggi.

\section{Hasil dan Pembahasan Hasil}

Penelitian tindakan kelas ini dilaksanakan pada anak kelompok B3 TK Kartika VII-3 Singaraja tahun 2018/2019 dengan jumlah subjek sebanyak 27 anak yang terdiri dari 9 orang anak perempuan dan 18 orang anak laki-laki. Penelitian ini dilaksanakan dalam II siklus. Tema yang digunakan pada saat penelitian ini berlangsung, mengikuti tema yang diterapkan oleh sekolah yaitu tema binatang. Data yang dikumpulkan adalah data tentang kemampuan bahasa mengenal huruf anak setelah diterapkan model pembelajaran Think Pair Share (TPS). Data tersebut dianalisis dengan menggunakan metode analisis statistik deskriptif dan metode analisis deskriptif kuantitatif. Kegiatan penelitian ini dilaksanakan pada bulan September - Oktober 2018. Hasil penelitian tersebut dapat dipaparkan sebagai berikut.

Pada siklus I dilaksanakan mulai dari tanggal 25 September sampai 28 September 2018 yang dilaksanakan dalam 4 kali pertemuan untuk melaksanakan penerapan dan 1 kali untuk melaksanakan evaluasi. Pelaksanaan siklus I ini dilaksanakan berdasarkan perencanaan pelaksanaan pembelajaran yang telah dibuat sebelumnya. Rencana Pelaksanaan Pembelajaran Mingguan serta Rencana Pelaksanaan Pembelajaran Harian (terlampir). Adapun tema pada siklus I ini adalah Tema Binatang. Berdasarkan hasil analisis data yang disajikan dalam grafik polygon menunjukkan bahwa Modus $<$ Median $<$ Mean $(7<8<8,85)$, sehingga dapat dikatakan bahwa sebaran data-data kemampuan bahasa mengenal huruf pada siklus I merupakan kurva juling positif. Dengan demikian dapat diinterpretasikan bahwa skor kemampuan bahasa mengenal huruf pada anak kelompok B3 di TK Kartika VII-3 Singaraja cenderung rendah. 


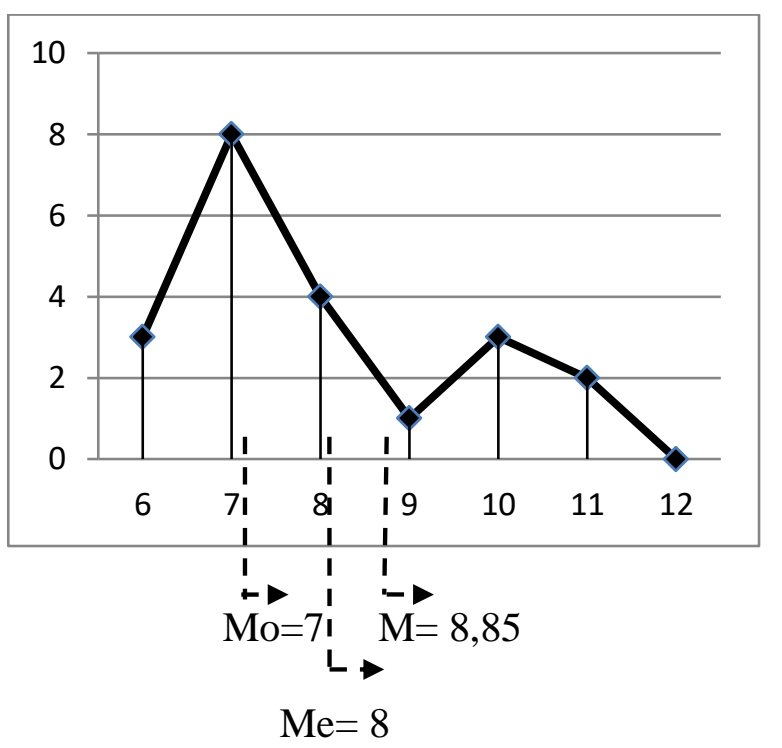

Gambar 4.1 Grafik Polygon Data Kemampuan Bahasa Mengenal Huruf Siklus I

Sedangkan untuk menghitung tingkat kemampuan bahasa mengenal huruf anak dapat dihitung dengan membandingkan rata-rata persentase (M\%) dengan Kriteria Pedoman Acuan Patokan (PAP) skala lima. Nilai M\%=55,31 \% yang dikonversikan kedalam PAP skala lima berada pada tingkat penguasaan 55-64 yang berarti bahwa tingkat kemampuan bahasa lisan anak pada siklus I berada pada kriteria rendah.

Berdasarkan hasil penelitian tersebut, maka dapat diketahui bahwa tingkat kemampuan bahasa mengenal huruf pada siklus I masih berada pada kriteria rendah. Adapun kendalakendala dan kekurangan penerapan model pembelajaran Think Pair Share (TPS) pada siklus I adalah sebagai berikut.(1) Penjelasan guru terlalu cepat, sehingga beberapa anak kebingungan saat belajar kelompok.(2) Keaktifan anak masih kurang, terlihat hanya beberapa anak yang mau menjawab pertanyaan guru dan tampil ke depan kelas.(3) Bentuk kartu huruf kurang bervariasi, sehingga anak mulai terlihat bosan pada akhir pertemuan pada siklus I.

Untuk mengatasi kendala-kendala tersebut, dalam melaksanakan siklus II akan dilakukan hal-hal sebagai berikut.(1) Menjelaskan kembali langkah-langkah model pembelajaran Think Pair Share (TPS) pada anak.(2) Membimbing dengan baik anak yang mempunyai kemampuan akademik tinggi agar dapat dan mampu menularkan pengetahuan anak kepada anak yang kurang aktif.(3) Menambah variasi warna pada kartu huruf dengan warna yang menarik.

Berdasarkan hasil refleksi tersebut, maka penelitian tindakan kelas ini perlu dilanjutkan ke siklus II untuk peningkatan dan penyempurnaan kemampuan bahasa mengenal huruf pada anak kelompok B3 di TK Kartika VII-3 Singaraja.

Pada siklus II dilaksanakan mulai dari tanggal 1 s/d 4 Oktober 2018 yang dilaksanakan dalam 4 kali pertemuan untuk melaksanakan penerapan dan 1 kali untuk melaksanakan evaluasi. Pelaksanaan siklus II ini dilaksanakan berdasarkan hasil dari refleksi sikus I.Rencana Pelaksanaan Pembelajaran Mingguan serta Rencana Pelaksanaan Pembelajaran Harian (terlampir). Adapun tema pada siklus II ini adalah Tema Binatang.

Berdasarkan hasil analisis data yang disajikan dalam grafik polygon menunjukkan bahwa Mean < Median < Modus $(12,96<13<14)$, sehingga dapat dikatakan bahwa sebaran data-data kemampuan bahasa keaksaraan pada siklus II merupakan kurva juling negatif. Dengan demikian dapat diinterpretasikan bahwa skor kemampuan bahasa lisan pada anak kelompok B3 di TK Kartika VII-3 Singaraja cenderung tinggi. Apabila disajikan dalam bentuk grafik polygon akan tampak sebagai berikut. 


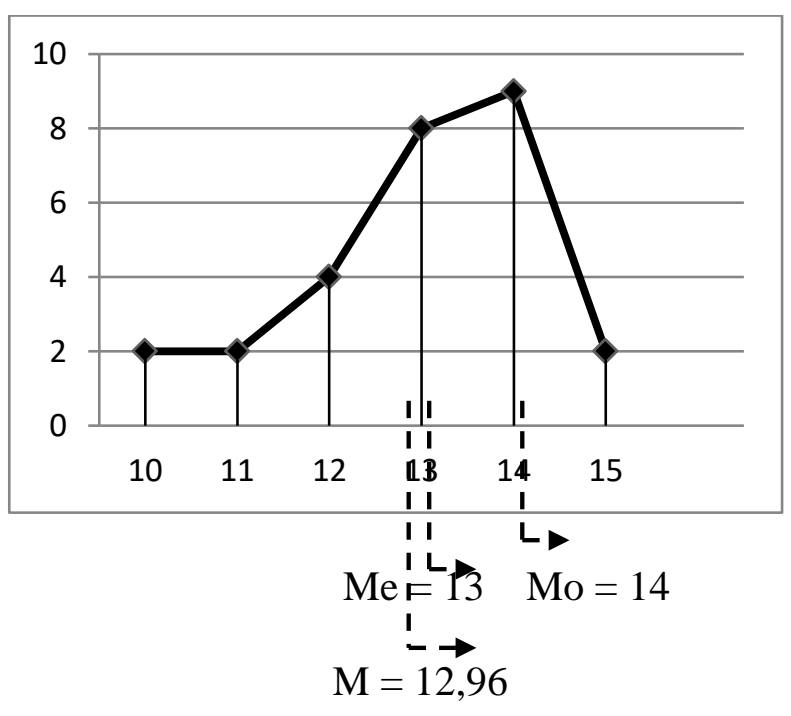

Gambar 4.2 Grafik Data Kemampuan bahasa mengenal huruf Siklus II

Sedangkan untuk menghitung tingkat kemampuan bahasa mengenal huruf anak dapat dihitung dengan membandingkan rata-rata persentase (M\%) dengan Kriteria Pedoman Acuan Patokan (PAP) skala lima. Nilai $M \%=81,01 \%$ yang dikonversikan kedalam PAP skala lima berada pada tingkat penguasaan 80-89 yang berarti bahwa tingkat kemampuan bahasa lisan anak pada siklus II berada pada kriteria tinggi

Setelah dilaksanakan perbaikan dari proses pembelajaran sikus I, dalam pelaksanaan siklus II terjadi peningkatan yang dapat dilihat pada kemampuan bahasa mengenal huruf anak yang sebelumnya berada pada kriteria rendah meningkat menjadi kriteria tinggi.

Adapun temuan-temuan yang diperoleh selama pelaksanaan siklus II adalah sebagai berikut.(1) Anak yang awalnya masih bingung dengan penerapan model pembelajaran Think Pair Share sudah dapat mengikuti setiap langkah penerapannya secara berurutan.(2) Anak yang awalnya kurang memahami konsep huruf sudah dapat mengetahuinya.(3) Anak yang awalnya belum bisa bekerjasama sudah bisa bekerjasama dengan baik (4) Bimbingan serta motivasi tetap diberikan pada anak.

Secara umum proses pembelajaran dengan menggunakan model pembelajaran Think Pair Share untuk meningkatkan kemampuan bahasa mengenal huruf anak kelompok B3 berlangsung sesuai dengan perencanaan dan telah mencapai indikator keberhasilan. Hal ini terlihat dari adanya peningkatan rata-rata persentase dari sikus I ke siklus II, sehingga penelitian ini tidak dilanjutkan ke siklus berikutnya.

\section{Pembahasan}

Berdasarkan hasil analisis data penelitian yang telah dilaksanakan dalam dua siklus menunjukkan terjadinya peningkatan kemampuan bahasa mengenal huruf anak kelompok B3 TK Kartika VII-3 Singaraja dengan menerapkan model pembelajaran Think Pair Share. Setelah dilaksanakan tindakan pada siklus I diperoleh rata-rata persentase yaitu 55,31\% pada kategori sedang menjadi $81,01 \%$ pada siklus II dengan kategori tinggi. Hal ini menunjukkan adanya peningkatan rata-rata persentase kemampuan bahasa mengenal huruf anak dari siklus I ke siklus II mencapai $25.7 \%$. Terjadinya peningkatan kemampuan pengenalan huruf (keaksaraan) pada anak setelah penerapan model pembelajaran Think Pair Share berbantuan media kartu huruf dalam penelitian ini disebabkan rasa tertarik anak pada kegiatan dan media pembelajaran yang disajikan oleh guru, sehingga anak dapat menyelesaikan tugas yang diberikan guru secara berkelompok, yang pada akhirnya mampu meningkatkan kemampuan mengenal huruf pada anak.

Pemberian stimulasi guna meningkatkan kemampuan mengenal huruf, perlu diberikan pada anak dengan cara yang tepat dan metode pembelajaran yang sesuai dengan 
perkembangan anak. Trianto (2009:81) mengungkapkan "keunggulan dari model pembelajaran TPS adalah optimalisasi partisipasi anak". anak dituntut aktif dalam kelompok, saling berbagi informasi dan membantu ketika salah satu teman mengalami kesulitan. Penerapan pembelajaran dengan berkelompok dan menggunakan media kartu huruf memberikan pengalaman kepada anak dalam mengenal huruf yang akan menjadi bekal persiapan anak untuk dasar belajar membaca. Bond dan Dykstra (Slamet Suyanto, 2005: 165) mengungkapkan "anak yang dapat mengenal huruf dengan baik cenderung memiliki kemampuan membaca dengan lebih baik". Karena mengenal huruf adalah tahapan mendasar sebelum belajar membaca.

Kemampuan anak dalam pengenalan huruf menggunakan metode TPS pada Siklus II menunjukkan sudah $81,01 \%$ anak-anak dalam 1 kelas memiliki kemampuan mengenal huruf dengan baik, disbanding dengan siklus I yang 55,31\% saja anak yang dapat mengenal huruf. Itu berarti dengan menggunakan metode Think Pair Share peningkatan dari Siklus I ke II mengalami peningkatan $25,7 \%$.

Berdasarkan penelitian yang telah dilakukan, secara umum peningkatan kemampuan mengenal huruf melalui metode Think Pair Share dengan berbantuan media kartu huruf, sudah berhasil meningkat hingga $81,01 \%$ dengan kriteria tinggi. Oleh karena itu, metode pembelajaran Think Pair Share dengan berbantuan kartu huruf dapat meningkatkan kemampuan bahasa anak dalam pengenalan huruf.

\section{Simpulan dan Saran}

Berdasarkan hasil analisis data dan pembahasan yang telah diuraikan dapat ditarik simpulan sebagai berikut. Terdapat peningkatan kemampuan bahasa I mengenal huruf pada anak kelompok B3 TK Kartika VII-3 Singaraja setelah diterapkan model pembelajaran Think Pair Share peningkatan mencapai $25,7 \%$. Hal ini terlihat dari peningkatan persentase rata-rata kemampuan bahasa lisan pada siklus I, $\mathrm{M} \%=55,31 \%$ yang berada pada kategori rendah menjadi sebesar $81,01 \%$ pada siklus II yang berada pada kategori tinggi. Dengan demikian dapat disimpulkan bahwa penerapan model pembelajaran Think Pair Share dapat meningkatkan kemampuan bahasa mengenal huruf kelompok B3 TK Kartika VII-3 Singaraja Tahun Pelajaran 2018/2019.

Berdasarkan simpulan tersebut, dapat diajukan saran - saran sebagai berikut.(1) Kepada para guru disarankan agar lebih kreatif dan inovatif dalam memilih model pembelajaran, metode pembelajaran serta media pembelajaran yang sesuai dengan Tema dan standar tingkat pencapaian perkembangan anak di laksanakan dengan cara yang menyenangkan supaya anak merasa tertarik dan mau mengikutinya. (2) Kepada Kepala TK, disarankan agar mampu memberikan pembinaan informasi tentang metode dan media pembelajaran yang menarik untuk diterapkan dalam proses pembelajaran sehingga mampu meningkatkan kreativitas anak dan perkembangan kemampuan anak.(3) Kepada penelitian lain disarankan untuk melakukan penelitian lebih lanjut pada penerapan model pembelajaran Think Pair Share (TPS) dengan berbantuan media kartu huruf untuk meningkatkan kemampuan bahasa mengenal huruf agar mencapai hasil optimal sebagai penyempurnaan dari penelitian ini.

\section{Daftar Pustaka}

Agung, A. A. Gede. 2014.MetodologiPenelitian Pendidikan. Malang: AdityaMedia Publish.

Aisyah, Siti, dkk. 2007. Perkembangan dan Konsep Dasar Perkembangan Anak Usia Dini. Jakarta : Universitas Terbuka.

Arikunto, Suharsimi. Dkk. 2015. Penelitian Tindakan Kelas. Jakarta: Bumi Aksara

Dimyanti, Johni. 2013. Metodologi Penelitian Pendidikan dan Aplikasinya Pada Anak Usia Dini. Jakarta: Kencana Prenada Media Group. 
Haryuni, Sri. 2013. "Peningkatan Kemampuan Mengenal Bilangan Melalui Media Domino di PAUD Kenanga 1 Pesisir Selatan". Spektrum PLS, Volume 1, Nomor 1 (hlm 104-118) Hariyanto, Agus. (2009). Membuat Anak Anda Cepat Pintar Membaca. Yogyakarta: Diva Press.

Hasan, Iqbal. 2003. Pokok-Pokok Materi Statistik 1. Jakarta: PT Bumi Aksara

Maimunah Hasan. 2009. Pendidikan Anak Usia Dini. Yogyakarta: Diva

Rusdiani, Luh Putu Dian. 2014." Penerapan Model Pembelajaran Think Pair Share (TPS) Berbantuan Media Pohon Bilangan Untuk Meningkatkan Kemampuan Berhitung Pada Kelompok B Semester II TK Anak Negeri Sangsit"

Sukardi. 2012. Metodologi Penelitian Pendidikan Kompetensi dan Praktiknya. Jakarta: PT Bumi Aksara

Trianto, 2009. Mendesain Model Pembelajaran Inovatif-Progresif. Jakarta : Kencana Prenada Media Group

Trianto. 2011. Panduan Lengkap Penelitian Tindakan Kelas Teori \& Praktik. Jakarta: Prestasi Pustakaraya.

Trianto. 2012. Mendesain Model Pembelajaran Inovatif- Progresif, Konsep, Landasan, dan Implementasinya pada Kurikulum Tingkat Satuan Pendidikan (KTSP). Jakarta: Kencana Prenada Media Group.

Wulandary, Nur Aisyah. (2013). "Pengaruh Penerapan Model Pembelajaran Kooperatif "Think Pair Share" Terhadap Kemampuan Mengenal Konsep Bilangan 1-10 Anak Kelompok A2 Di TK Dharma Wanita Persatuan Lowayu Kabupaten Gresik”. Jurnal Pendidikan, Volume 1, Nomor 1 (hlm 1-3) 